\section{New law needs changes made}

\section{Munich}

A draft 'framework law' regulating genetic engineering in West Germany was attacked by environmentalists as not being tough enough at a parliamentary hearing in Bonn last week. But members of the conservative majority, while admitting the need for some changes, remain confident that the law will be passed later this year.

The government must act quickly because a November 1989 court decision forbids the use of genetic engineering in industry until there is a legal basis for regulating the technology. The ruling forced Hoechst AG to stop construction of a nearly completed facility.

Adding to the pressure is the knowledge that a majority of the Länder (states), which are represented in the upper house of parliament, must approve the law for it to take effect. The conservative coalition of Helmut Kohl has a majority in the upper house at present, but that could change in an election in Lower Saxony on 13 May. If the law cannot be passed by then, the opposition parties may attempt to make it more restrictive.

The acrimonious three-day hearing was dominated by activists who claim that genetic engineering is an inherently hazardous technology. The text of the law seems to concur - the first paragraph states that a law is needed in order to protect "life, property and the environment ... from the dangers of genetic engineering . . .". But the biotechnology industry supported the law at the hearing, and basic research organizations said they could live with it, if there must be one, as long as a few changes are made.

Not all the changes are likely to please industry. The biggest change expected will give the Länder, not Bonn, the authority to grant licences to basic research laboratories as well as to factories that use recombinant DNA technology.

Ernst-Ludwig Winnacker, vice-president of the Deutsche Forschungsgemeinschaft, said that if this happens, he fears uneven treatment of licence applications in the different Länder. He questions whether there are enough qualified experts in West Germany to fill all the review committees. But Winnacker hopes that the Länder will accept decisions made by the Central Commission for Biological Safety (ZKBS in German), which currently issues opinions on licensing matters.

Almost certain to change is the composition of ZKBS. ZKBS is composed of eight biologists and four representatives of unions, industry, environmental and research organizations. But parliamentarians of all parties seem to feel that the committee contains too many 'experts' who will inevitably favour genetic

engineering. Winnacker criticized this thinking, saying that the government will retain the power to overrule ZKBS so that there is no need to pack it with people without a scientific background.

The West German law must fit with an European Communities (EC) directive on genetic engineering that will take effect next year. The EC directive foresees just two safety classifications for genetically manipulated microorganisms used in confinement, whereas the West German law foresees four levels.

Winnacker would like to see the West German law adapted to the EC directive in other ways too, for example by removing from regulation certain nonrecombinant methods that lead to gene transfer, such as mutagenesis, hybridoma formation and protoplast fusion.

Although he was glad that the release of genetically engineered organisms into the environment will be allowed under the new law, Winnacker warned that the law does not distinguish between different types of release. Certain harmless forms of release, such as the sale of transgenic UK UNIVERSITIES

\section{London}

AN injection of $£ 259$ million is needed to meet the demand for research equipment in UK universities, according to a report to be published shortly by the Advisory Board for the Research Councils (ABRC). The report, compiled by Luke Georghiou, Peter Halfpenny and Susan Hinder of the University of Manchester, also shows that researchers in more than 80 per cent of university departments feel that critical experiments are either prevented, or delayed, because of lack of equipment.

The survey took the form of detailed questionnaires, issued to university departments in 1988, and looked at equipment in the $£ 10,000$ to $£ 1$ million price range. Researchers had to explain how desired items of equipment were needed.

Many of the required items of equipment were more expensive than the average cost of equipment surveyed, suggesting that there is a particular problem in funding for more expensive equipment, such as spectrometers and nuclear magnetic resonance (NMR) equipment.

British academics also believe their laboratories fall below top international standards. Eighty-one per cent of departments felt they were well-equipped by UK standards, but only 22 per cent thought this was the case in international terms. British equipment was markedly older than that in US universities surveyed by the National Institutes of Health and the

\title{
Equipment lack documented
}

animals and plants, must be specifically allowed by the law, he said.

One improvement, from the point of view of industry, will come with the introduction of a one-step licensing procedure for factories that use genetic-engineering technology. All the issues raised by the use of genetic engineering will be addressed in a single public hearing. Once this is over, the company can use the factory in question for a variety of techniques without requiring a new hearing for each microbial strain.

Coalition member Heinrich Seesing (Christian Democrat), who is a member of the subcommittee responsible for the law, was confident that it could be rewritten and passed in time. "There is a majority in parliament in favour of allowing both genetic engineering and environmental release", he said.

But opposition member Edelgard Bulmahn (Social Democrat), who is also on the subcommittee, warned that trying to push the law through parliament against the will of the opposition would be very unwise. She said that the Länder governed by Social Democrats would balk at administering a law they found unsatisfactory.

Steven Dickman

National Science Foundation in the mid$1980 \mathrm{~s}$. These surveys judged US facilities inadequate and led to calls for upgrading.

Both Georghiou and Halfpenny believe that more rigorous international comparisons are an important next step in their work. Georghiou says that data from new US surveys, France and West Germany will be re-analysed along the same lines as their own survey.

Apart from a massive injection of cash, the ABRC report identifies greater sharing of equipment between institutions as a potential solution to the problem. The report shows that, on average, equipment lies unused for 26 per cent of the time. Some schemes to promote equipment sharing do already exist. The Science and Engineering Research Council (SERC) runs loan pools for some equipment, and demands wider access as a condition when some expensive items, such as NMR equipment, are awarded to particular institutions. Geoff Richards, of SERC's science division, believes that equipment sharing has an important role to play, but this role is "limited by the demands of the science involved".

Scientists surveyed in the ABRC study were not happy with current arrangements for access to nominally shared equipment. Hinder, one of the authors, believes that a more formalized system for sharing is needed.

Peter Aldhous 